\title{
Constraints Faced by the Farm Families in Adoption of Post Harvest Technologies of Maize
}

\author{
Chamandeep Kaur ${ }^{1}$, Dhriti Solanki ${ }^{2}$ and L. R. Choudhary ${ }^{3 *}$ \\ ${ }^{1}$ Department of Home Science, KVK Sawai Madhopur, Rajasthan, India \\ ${ }^{2}$ Department of HECM, College of H.Sc, MPUAT, Udaipur, Rajasthan, India \\ ${ }^{3}$ Department of Agriculture Extension, KVK, Gudamalani, Barmer, Rajasthan, India \\ *Corresponding author
}

\begin{tabular}{|l|}
\hline Ke y w o r d s \\
Panchayat samities, \\
$\begin{array}{l}\text { Bio-fuel, Needs, } \\
\text { Opportunities and } \\
\text { prospects }\end{array}$ \\
\hline Article Info \\
\hline $\begin{array}{l}\text { Accepted: } \\
\text { 04 November } 2019 \\
\text { Available Online: } \\
\text { 10 December } 2019\end{array}$ \\
\hline
\end{tabular}

A B S T R A C T
The present study was undertaken to assess and compare the knowledge of improved maize production and post harvest technologies among farmers and farm women and constraints faced by the farm families in adoption of maize production technologies of maize. The study was conducted in two purposively selected districts viz. Udaipur and Chittorgarh of Agro-climatic zone IV A of Rajasthan. Two panchayat samities from each district were selected purposively and three villages from each panchayat samiti were selected on random basis. Thus, there were total six villages from each district and total 12 villages from both the districts. Fifteen farm families from each village and 90 farm families from each district were selected. One male and one female member of the farm family who was actively involved in maize cultivation was included in the sample. Thus, total sample for the present study was 360 respondents (180 farmers and 180 farm women). The interview schedule consisted of four sections i.e. personal characteristics of the respondents Constraints in adoption of improved maize production technologies by the farm families. The most important constraint faced by farm families was damage of maize field by the blue bulls due to absence of proper fencing (96.11 MPS). The other constraints faced by the farm families in adoption of improved maize production and post harvest technologies were high labour charges (93.06 MPS), unavailability of labour and fragmented land holdings (91.11 MPS), high cost of farm implements (87.50 MPS), agricultural inputs (83.89 MPS).

\section{Introduction}

Agriculture plays a vital role in the Indian economy as it contributes about 17 per cent to the total GDP and provide livelihood to 65 to 70 per cent of the total population. The sector provides employment to 58.4 per cent of country's workforce and is the single largest private sector occupation. India's foreign trade is deeply associated with agriculture sector as it accounts for about 14.7 per cent of the total export earnings. Indian agriculture has registered impressive growth over last few decades. However, Indian agriculture is faced 
with a great diversity of needs, opportunities and prospects. Food demand is expected to be doubled by 2050, while production environment and natural resources are continuously shrinking and deteriorating.

Inadequate attention to agriculture has led to steep rise in food prices and increased food riots. Food crisis has aggravated further because of climate change and diversion of arable lands to urbanization, industrialization and also for producing bio-fuel. The challenge to agriculture in coming years is immense (ICAR Vision, 2030).

Apart from facing the challenge of increasing the food production in the country, the another challenge which the Indian farmers are facing is to reduce the losses of food grain which occurs at different stages of post harvest operations after harvesting till marketing of the produce. Post harvest handling is the stage of crop production immediately following harvest, including cooling, cleaning, sorting and packing. The instant a crop is removed from the ground, or separated from its parent plant, it begins to deteriorate. Post harvest treatment largely determines final quality, whether a crop is sold for fresh consumption, or used as an ingredient in a processed food product. The most important goals of post harvest handling are to keep the product cool, avoid moisture loss and slow down undesirable chemical changes and to avoid physical damage such as bruising, to delay spoilage. Sanitation is also an important factor to reduce the activities of pathogens that could be carried by fresh produce. The post harvest management and loss prevention of food grains is prime responsibility of farm women as the operations like winnowing, drying and storage of produce are predominately done by them. Due to illiteracy and lack of scientific knowledge million tones food grains are either damaged or lost. Although intensive efforts have been made by the Government for dissemination of technologies related to post harvest however, there is conspicuous sex bias in extension and training programmes of women. The bias is so deeply rooted that in areas where women's participation is almost monopoly like winnowing, drying, storage and processing of grains etc., the men are being trained. The result is that women is totally ignored and unaware about scientific methods of post harvest and are bound to use traditional practices which are passed from generation to generation. In order to minimize the post harvest losses there is utmost need to educate the farm families especially women about scientific methods of grain storage to enable them to make the maximum use of available produce in term of quality and quantity.

Generally, losses in cereals and pulses during the post-harvest operations amount to about 810 per cent of field production (Hand book of Agriculture, 2011). Hence, in order to improve agriculture situation in the country the special attention has to be given towards minimization of post harvest losses.

\section{Materials and Methods}

The present study was conducted in the Agroclimatic zone IV A i.e. Sub- humid Southern Plain and Aravali Hills of Rajasthan State. Zone IV A covers all the tehsils of Bhilwara and Rajsamand districts, all tehsils of Udaipur district except Dhariyawad, Salumber and Sarada, all tehsils of Chittorgarh district and Aburoad and Pindwara tehsils of Sirohi district. Out of these, two districts namely Udaipur and Chittorgarh were selected purposively on the basis of highest production of maize. Zone IV- A of Rajasthan covers fourteen panchayat samities of Udaipur and eleven of Chittorgarh district. Out of these, two panchayat samities from each district were selected purposively on the basis of highest production of maize. Thus, from Udaipur district, Mavli and Girwa panchayat 
samities and from Chittorgarh district, Begu and Chittorgarh panchayat samities were selected. In each district, panchayat samiti wise list of villages was prepared and from the list three villages from each panchayat samiti were selected on random basis. Thus, there were six villages from each district making total 12 villages from both the districts. For selection of sample, a comprehensive list of maize growers was prepared from each identified village with the help of village Patwari and Agricultural Supervisor of the respective village and was categorized as small, marginal and large farmers on the basis of land holding. From each category, five farm families were selected from each village on random basis. Thus, there were 15 farm families from each village and 90 farm families from each district. One male and one female member of the farm family who was actively involved in maize cultivation was included in the sample. Thus, total sample for the present study was 360 respondents (180 farmers and 180 farm women).

\section{Results and Discussion}

In the present study, the term constraint means the barriers or obstacles which were perceived by the maize growers in the adoption of improved maize production and post harvest technologies. It is needless to mention that pace of adoption can be augmented by overcoming the perceived constraints. So, it was felt necessary to find out the major constraints which prevented the farm families from adoption of improved maize production and post harvest technologies. The constraints were grouped under five areas as technical, service-supply, economical, institutional and general. The results are presented as under:-

\section{Technical constraints}

Table 1 presents information about technical constraints faced by the maize growers in adoption of improved maize production technologies. Perusal of the table reveals that "hybrid seeds require more number of irrigation" was expressed as one of the most important constraints and ranked first by the respondents with MPS 62.22. This was due to the reason that the maturity period of hybrid seeds is 110-120 day whereas, in case of deshi seeds the maturity period is only 80 days.

The other constraints reported by the respondents were "hybrid seed requires high amount of fertilizers" and "poor germination of hybrid seeds" with MPS 53.89 and 53.61 and ranked II and III, respectively. Similarly, farmers also expressed that there is no surety of high yield in case of hybrid seeds (MPS 52.78, rank IV).

"Hybrid variety seeds are not suited to the rain-fed condition" was the another constraint faced by the farm families with 51.94 MPS and ranked V. Likewise, the farm families also experienced the problem of lack of training facilities for acquiring new technology and Agriculture Supervisor not able to solve the technical problems with MPS 51.39 and 46.67 and ranked VI and VII, respectively. The respondents reported that the trainings are organized at KVKs and office of State Department of Agriculture which are located at distant place from their village and many a times they felt difficulty in attending the training programmes.

Table 2 contains information about service supply-constraints faced by the farm families in adoption of improved maize production technologies. Perusal of the table depicts that majority of the farm families faced problem related to "unavailability of labour" with MPS 91.11 and ranked as $1^{\text {st }}$ in severity. The farm families reported that during peak season they faced difficulty in getting labour for farm work as most of the laborers were engaged in MGNEREGA. 
The other constraints reported by the farm families were "high cost of farm implements" and "non-availability of improved implements" with MPS 87.50 and 72.22 and rank II and III, respectively. Similarly, farm families also expressed that there is inadequate availability of fertilizers with MPS 30.56 (rank IV). "Unavailability of improved seed in time" and "unavailability of insecticides, pesticides at Kisan Seva Kendra" were the other constraints faced by the farm families with MPS 20.28 and 18.06 and rank V \& VI, respectively. The findings are similar to Solanki (2012) reported that major constraints experienced by the maize growers were non availability of fertilizers in time, non availability of seed in required quantity and high cost of seed, fertilizers and chemicals. Some of the farm families also faced the problem of inadequate and untimely rainfall with MPS 8.33 and rank VII. Respondents reported that due to untimely rainfall they could not follow the recommended time of sowing in maize due to which the yield is adversely affected.

\section{Economic constraints}

Economic constraints faced by the farm families in adoption of improved maize production technologies are presented in Table 3. Perusal of the table depicts that majority of the farmers faced problems related to "high labour charges" and "fragmented land holding" with MPS 93.06 and 91.11 and rank I \& II, respectively. The farmers reported that during peak season the labour charges are very high which is beyond their capacity as majority them belonged to low socioeconomic status (Table 3). The other constraints reported particularly by the small and marginal farm families were "high cost of inputs like seeds, fertilizers, chemicals" and "low prices of maize in the market" with MPS
83.89 and 70.83 and rank III \& IV, respectively.

Similarly, farm families also expressed that there is high rate of interest on loans taken by using Kisan credit card (MPS 63.89, rank V)."Poor economic condition" and "poor return as compared to soybean / green gram/ groundnut / black gram " were the other constraints faced by farm families with MPS 55.56 and 51.67 and rank VI \& VII, respectively. Likewise, the farm families also experienced the problems related to lack of finance facilities with MPS 16.67 and rank VIII. The respondents also expressed that the net return from maize is very less as compared to other crops viz. soybean, groundnut, black gram and green gram.

The findings are in line with Sharma and Sharma (2008) who concluded that constraints faced by the respondents in adoption of improved bajra production were high cost of fertilizers $(71.25 \%)$, high cost of plant protection chemicals (42.50\%) and not much return against investment (71.25\%). Inadequate capital and lack of technical guidance $(60.00 \%)$ were the other constraints faced by the farmers in the study area.

\section{Institutional constraints}

Table 4 reveals that institutional constraints were not faced to a great extent by the farm families however, some of the problems experienced by them were "lack of active local leaders "(MPS 13.06) and "lack of trainings to the Agricultural Supervisors (MPS 8.06)". The respondents reported during discussion that many a times the Agriculture Supervisor is not in a position to solve technical problems and they suggested that training programmes should be organized for them to keep abreast with latest knowledge. 
Table.1 Technical constraints faced by farm families in adoption of maize production technologies

\begin{tabular}{|c|c|c|c|}
\hline S. No. & Technical Constraints & MPS & Rank \\
\hline 1 & Hybrid seeds requires more number of irrigation & 62.22 & I \\
\hline 2 & Hybrid seeds requires high amount of fertilizer & 53.89 & II \\
\hline 3 & Poor germination of hybrid seeds. & 53.61 & III \\
\hline 4 & Not sure if hybrid will give higher yields & 52.78 & IV \\
\hline 5 & Hybrid seeds are not suited to the rain fed conditions & 51.94 & $\mathrm{~V}$ \\
\hline 6 & Lack of training facility for acquiring new technology & 51.39 & VI \\
\hline \multirow[t]{2}{*}{7} & $\begin{array}{l}\text { Agriculture Supervisor not able to solve technical } \\
\text { problems }\end{array}$ & 46.67 & VII \\
\hline & Total & 46.56 & \\
\hline
\end{tabular}

Constraints related to service-supply

Table. 2 Service supply constraints faced by farm families in adoption of maize production technologies

\begin{tabular}{|c|c|c|c|}
\hline & & & $\mathrm{n}=180$ \\
\hline S. No. & Service Supply Constraints & MPS & Rank \\
\hline 1 & Unavailability of labour. & 91.11 & I \\
\hline 2 & High cost of farm implements. & 87.50 & II \\
\hline 3 & Non-availability of improved implements. & 72.22 & III \\
\hline 4 & Unavailability of adequate fertilizers & 30.56 & IV \\
\hline 5 & Unavailability of improved seeds in time & 20.28 & V \\
\hline 6 & $\begin{array}{l}\text { Unavailability of insecticides, pesticides at Kisan } \\
\text { Seva Kendar }\end{array}$ & 18.06 & VI \\
\hline \multirow[t]{2}{*}{7} & Inadequate and untimely rainfall. & 8.33 & VII \\
\hline & Overall & 46.87 & \\
\hline
\end{tabular}

Table.3 Economic constraints faced by farm families in adoption of maize production technologies

\begin{tabular}{|c|c|c|c|}
\hline S. No. & Economic Constraints & MPS & Rank \\
\hline 1 & High labour charges & 93.06 & I \\
\hline 2 & Fragmented land holding & 91.11 & II \\
\hline 3 & $\begin{array}{l}\text { Higher cost of inputs like seeds, fertilizers and } \\
\text { chemicals }\end{array}$ & 83.89 & III \\
\hline 4 & Low price of maize in the market & 70.83 & IV \\
\hline 5 & $\begin{array}{l}\text { High rate of interest on loan taken by using Kisan credit } \\
\text { card }\end{array}$ & 63.89 & V \\
\hline 6 & Poor economic conditions & 55.56 & VI \\
\hline 7 & $\begin{array}{l}\text { Poor net return as compared to soybean / green gram/ } \\
\text { groundnut / black gram }\end{array}$ & 51.67 & VII \\
\hline \multirow[t]{2}{*}{8} & Lack of finance facility & 16.67 & VIII \\
\hline & Overall & 65.83 & \\
\hline
\end{tabular}


Table.4 Institutional constraints faced by farm families in adoption of maize production technologies

\begin{tabular}{|c|l|c|c|}
\hline S. No. & Institutional Constraints & MPS & Rank \\
\hline $\mathbf{1}$ & Lack of active local leaders & 13.06 & I \\
\hline $\mathbf{2}$ & Lack of training to the agricultural supervisors & 8.06 & II \\
\hline $\mathbf{3}$ & Inadequate no. of training for farm women & 7.78 & III \\
\hline $\mathbf{4}$ & Lack of adequate technical guidance to farmers & 6.94 & IV \\
\hline $\mathbf{5}$ & Lack of women extension personnel at village level & 3.61 & V \\
\hline & Overall & $\mathbf{5 . 6 3}$ & \\
\hline
\end{tabular}

Table.5 General constraints faced by farm families in adoption of maize production technologies

\begin{tabular}{|c|c|c|c|}
\hline S. No. & General Constraints & MPS & Rank \\
\hline $\mathbf{1}$ & Damage of maize field due to blue bulls & 96.11 & I \\
\hline $\mathbf{2}$ & Lack of co-ordination among the farmers & 6.11 & II \\
\hline & Overall & $\mathbf{3 4 . 0 7}$ & \\
\hline
\end{tabular}

Table.6 Constraints faced by farm families in adoption of maize production technologies

\begin{tabular}{|c|c|c|c|}
\hline & & & $\mathrm{n}=180$ \\
\hline S. No. & Constraints & MPS & Rank \\
\hline 1 & Economic Constraints & 65.83 & I \\
\hline 2 & Service - Supply constraints & 46.87 & II \\
\hline 3 & Technical constraints & 46.56 & III \\
\hline 4 & General Constraints & 34.07 & IV \\
\hline 5 & Institutional constraints & 5.63 & V \\
\hline & Overall & 45.63 & \\
\hline
\end{tabular}

Other constraints experienced by the respondents were "inadequate number of trainings for farm women" (MPS 7.78) and "lack of adequate technical guidance to farmers" (MPS 6.94) and ranked as III and IV, respectively. The women also expressed the problem of "lack of women extension personnel (MPS 3.61) and ranked V. They reported that extension personnel faced difficulty in solving their technical problems as they felt hesitation in communication with the male members.

\section{General constraints}

Apart from technical, service supply, economic and institutional constraints the respondents were facing some general constraints in adoption of maize production technologies which are presented in Table 5.

Table 5 evident that the major problem experienced by almost all the farm families was damage of maize field by the blue bulls due to absence of proper fencing (MPS 96.11 and rank I). The findings were in accordance with Dhaka et al., (2010) who reported that the major problem for poor adoption of maize cultivation technology by the farmers was damage by wild animals. The another constraint reported by the farm families was "lack of co-ordination among the farmers" with MPS 6.11 and rank II. Table 6 reveals that among all the constraints economic 
constraints were the most severe with MPS 65.83 and rank I. The other constraints faced by the respondents were service-supply with MPS 46.87 and rank II followed by technical, general and institutional constraints with MPS 46.56, 34.07 and 5.63 and rank III, IV and V, respectively.

\section{References}

Handbook of Agriculture.2011.Published by Directorate of Knowledge Management in Agriculture, ICAR, New Delhi-110 012.
ICAR Vision 2030.2011. Retrieved from www.icar.org.in/files/ICAR.vision2030.Pdf on October 22nd, 2013.

Jideani, Afam I.O.; Anyasi, Tonna A.; Mchau, Godwin R.A.; Udoro, Elohor O.; Onipe, Oluwatoyin O. (13 September 2017). "Processing and Preservation of Fresh-Cut Fruit and Vegetable Products". Postharvest Handling. InTech. doi:10.5772/intechopen.69763.

$\wedge$ Janet Bachmann and Richard Earles (August 2000). "Postharvest Handling of Fruits and Vegetables". NCAT. Archived from the original on 2002-02-11.

\section{How to cite this article:}

Chamandeep Kaur, Dhriti Solanki and Choudhary, L. R. 2019. Constraints Faced by the Farm Families in Adoption of Post Harvest Technologies of Maize. Int.J.Curr.Microbiol.App.Sci. 8(12): 101-107. doi: https://doi.org/10.20546/ijcmas.2019.812.016 